\title{
Diagnostic accuracy of serum endothelin-1 in patients with HCC on top of liver cirrhosis
}

\author{
Mohammad M. Elbadry ${ }^{1}$, Mina Tharwat ${ }^{1 *}$, Emad F. Mohammad $^{2}$ and Ehab F. Abdo ${ }^{3}$
}

\begin{abstract}
Background: Hepatocellular carcinoma (HCC) is one of the most common cancers and one of the main causes of cancer-related deaths. As the overall survival of patients with cirrhosis has improved and the global incidence of HCC has continued to increase, strategies for the early detection of HCC are urgently needed for better prognosis. In this study, we aimed to assess the accuracy of endothelin-1 in the diagnosis of HCC in cirrhotic patients in comparison with alpha-fetoprotein (AFP) and whether it could predict its vascular spread. This is a case-control study that included 70 cirrhotic patients with or without hepatocellular carcinoma. Patients were subjected to complete medical history taking, clinical examination and laboratory investigations including serum endothelin-1, alpha-fetoprotein, abdominal ultrasound and Triphasic multi-slice computed tomography (CT; abdomen and pelvis). The outcome results obtained for endothelin-1 were used to assess its diagnostic accuracy in HCC diagnosis and the prediction of presence of vascular spread.

Results: There was a statistically significant increase in serum endothelin-1 in HCC in comparison to cirrhotic patients and normal persons ( $P$ value $<0.001)$. Sensitivity, specificity, and positive and negative predictive values at cut-off point of $5.2 \mathrm{pg} / \mathrm{ml}$ for HCC were $90 \%, 100 \%, 100 \%$, and $90.9 \%$ respectively. There was no statistically significant association between serum endothelin-1 level and portal vein thrombosis in HCC ( $P$ value $=0.547)$.
\end{abstract}

Conclusion: Endothelin-1 has high sensitivity and specificity for diagnosis of hepatocellular carcinoma. However, it has little value for prediction of its vascular spread.

Keywords: HCC, Prediction, Endothelin-1, Cirrhosis

\section{Background}

Hepatocellular carcinoma $(\mathrm{HCC})$ is one of the most common malignant tumors with high mortality and morbidity, in addition to aggressive growth behavior and a high recurrence rate [1]. HCC is common in patients with liver cirrhosis; it usually develops following chronic liver inflammation caused by hepatitis $\mathrm{C}(\mathrm{HCV})$ or $\mathrm{B}$ (HBV) virus. Egypt has the highest prevalence of HCV in the world. Therefore, HCC represents an important public health problem in Egypt [2]. The prognosis of well

\footnotetext{
* Correspondence: minatharwat_tropical@yahoo.com

${ }^{1}$ Tropical Medicine and Gastroenterology Department, Faculty of Medicine, Aswan University, Aswan, Egypt

Full list of author information is available at the end of the article
}

differentiated HCC is good following curative treatment such as resection or local therapy, while the prognosis of poorly differentiated HCC is poor due to greater tendency for vascular invasion and distant metastasis [3, 4]. As only small tumors are eligible for curative treatment (radiofrequency, resection, or transplantation), surveillance of cirrhotic patients is recommended by European and American societies [5]. Thus, the discovery of novel markers to detect $\mathrm{HCC}$ appears to be the best strategy for promoting the long-term therapeutic outcome [6, 7]. Current screening programs are based on alpha-fetoprotein (AFP) assay and abdominal ultrasound scans (US) [8]. Concerning the modalities of surveillance, US sensitivity depends on the experience of the operator and on different

\section{Springer Open}

(c) The Author(s). 2020 Open Access This article is licensed under a Creative Commons Attribution 4.0 International License, which permits use, sharing, adaptation, distribution and reproduction in any medium or format, as long as you give appropriate credit to the original author(s) and the source, provide a link to the Creative Commons licence, and indicate if changes were made. The images or other third party material in this article are included in the article's Creative Commons licence, unless indicated otherwise in a credit line to the material. If material is not included in the article's Creative Commons licence and your intended use is not permitted by statutory regulation or exceeds the permitted use, you will need to obtain permission directly from the copyright holder. To view a copy of this licence, visit http://creativecommons.org/licenses/by/4.0/. 
factors of the tumor such as its site and size [9]. Also, serum AFP is not so useful due to the high rate of falsenegative and false-positive results [10].

The endothelins (ETs) are a family of genes consisting of three 21-amino-acid proteins including peptides ET1, ET-2, and ET-3 [11, 12]. Production of ETs was attributed to endothelial cells, later it was found that other cell types, like macrophages, produce ETs [13]. Earlier studies focused on the effects of ETs on systemic vasoregulation. Recent data suggested that they may regulate blood flow in specific tissues. This is of great importance for the liver, where changes in blood flow may play an important role in major events like portal hypertension, ascites formation, and hypoxic damage [14]. ET-1 is a very potent vasoconstrictor and binds to ET-A and ET-B receptors to trigger the downstream signaling of cells [15]. ET-A receptors are typically located on vascular smooth muscle cells and mediate vasoconstriction, whereas ET-B receptors are located on endothelial cells and stimulate endothelial nitric oxide (NO) synthase activity and NO release $[13,16]$. Many studies found that ET-1 and its receptors are over expressed in many cancers including colon and ovarian cancers $[17,18]$, and ET-1 expression in thyroid carcinoma correlate with characteristics such as growth and lymph node metastasis [19]. In prostate cancer, blocking of endothelin receptor inhibits disease progression [20]. A study reported that over expression of ET-1 triggers hepatocarcinogenesis in zebra fish [21]; however, studies about its role in diagnosis of HCC were limited. The current study aimed to assess the accuracy of endothelin-1 in the diagnosis of hepatocellular carcinoma in cirrhotic patients in comparison with alpha-fetoprotein in addition to its role in the prediction of $\mathrm{HCC}$ vascular spread.

\section{Methods}

In this case-control study, 70 patients who attended to Aswan University Hospital in the period from September 2016 to June 2018 were enrolled in the study after confirming the diagnosis of HCC by triphasic multi-slice CT. Patients with previously ablated hepatocellular carcinoma and those with secondary liver metastasis or with extra-hepatic malignancy were excluded from the study.

All enrolled patients were subjected to complete history taking, through physical examination especially manifestations of cirrhosis and portal hypertension and imaging study in the form of abdominal ultrasonography with stress on size, surface, and echopattern of the liver; hepatic focal lesions as regard to their site, size number, and echogenicity; portal vein diameter and its patency; size of the spleen; and detection of porto-systemic collaterals, ascites or presence of abdominal lymphadenopathy. Patients who had hepatic focal lesion by ultrasound were subjected to triphasic multi-slice CT abdomen \& pelvis to confirm diagnosis of hepatocellular carcinoma with full assessment of number, size, site, and extent of the tumor, to detect the presence or absence of local spread such as lymphadenopathy and the presence or absence of vascular invasion such as portal vein thrombosis. Based on the results of triphasic multi-slice CT abdomen, patients were diagnosed as having hepatocellular carcinoma (HCC) or not. Diagnosis of liver cirrhosis was based on liver function tests and abdominopelvic ultrasound. Accordingly, patients were categorized into 3 groups: group I consisted of 30 patients with liver cirrhosis and HCC, group II consisted of 30 patients with liver cirrhosis only; however, group III included 10 persons without liver cirrhosis or HCC as a control group.

From every studied subject $10 \mathrm{ml}$ of venous blood were drawn, under complete aseptic conditions. Each sample was divided into three portions: $2 \mathrm{ml}$ of blood into EDTA (Ethylene Diamine Tetra Acetic Acid) vacutainer tubes used for complete blood count, done on sysmex XP-300 cell counter, $8 \mathrm{ml}$ in plain tube which were left for clotting then centrifuged for serum collection to be used for routine and special parameter estimation. Routine parameter estimation (glucose, renal and liver function tests, etc) were done on fully automated chemistry analyzer BT-3500 (Italy). The other 2 tubes ( $2 \mathrm{ml}$ for each) have been frozen at $20^{\circ} \mathrm{C}$ for later use for estimation of both serum Endothelin-1 (ET-1) level by ELISA technique and alpha-fetoprotein which were done on automated chemilluminescence analyzer (Advia Centure, Siemens). Hemolyzed samples were excluded from the study.

ET-1 was determined by Sandwich ELISA technique (SinoGeneclon Biotech Co.). First, Human ET-1 antibody was adopted on coated microtiter plate to make solid phase antibody, then ET-1 samples were added to wells (patients, controls, and standards). ET-1 antibody was combined with labeled HRP (horse radish peroxidase) to form antibody-antigen-enzyme-antibody complex, then after washing completely, TMB (tetra-methyl-benzidine) substrate solution was added. TMB substrate turned blue color at presence of enzyme-catalyzed HRP; reaction was terminated by the addition of a stop solution and the color change was measured at a wavelength of $450 \mathrm{~nm}$. The concentration of ET-1 in the samples was then determined by comparing the optical density (OD) of the samples to the standard curve.

\section{Statistical analysis}

Data were collected, coded, and revised then analyzed using the Statistical Package for Social Science (IBM SPSS) version 20 . The data were presented as number and percentages for the qualitative data. For the quantitative data with parametric distribution mean, standard deviations and ranges were calculated, while for the quantitative data with non-parametric distribution, 
median with inter quartile range (IQR) was calculated. Chi-square test was used in the comparison between two groups with qualitative data and Fisher exact test was used instead of the Chi-square test when the expected count in any cell was found to be less than 5 . The comparison between more than two groups with quantitative data and parametric distribution was done by using One-Way Analysis of Variance (ANOVA) test and Kruskall-Wallis test was used in the comparison between more than two groups with quantitative data and nonparametric distribution. Spearman correlation coefficients were used to assess the significant relation between two quantitative parameters in the same group. Receiver operating characteristic (ROC) curve was used to assess the best cutoff point between the groups with its sensitivity, specificity, positive predictive value (PPV), negative predictive value (NPV), and area under the curve (AUC). The cutoff point was estimated using the Youden index (J) method. This method defines the optimal cut-point as the point maximizing the Youden function which is the difference between true positive rate and false positive rate over all possible cut-point values [22]. The confidence interval was set to $95 \%$ and the margin of error accepted was set to $5 \%$. So, the $P$ value was considered significant as the following: $P<0.05$, Significant; $P<0.01$, Highly significant.

The results of endothelin-1 were subjected to statistical analysis in comparison with clinical data \& investigations in all patients to assess the accuracy of endothelin-1 in diagnosis of HCC and assess its role in detection of tumor prognosis. Sensitivity, specificity, positive predictive value, negative predictive value, and diagnostic accuracy were calculated for endothelin-1. *Accuracy was defined by dividing the sum of the true positives and true negatives by the total number of samples evaluated. Pearson correlation $(R)$ value was calculated for each of them.

\section{Results}

This study included 60 patients and 10 persons as a control group; those who attended to Aswan University Hospital from September 2016 to June 2018; mean age was $62.66 \pm 8.8$ years, 57 patients $(81.42 \%)$ were men and 30 (42.58\%) were from urban areas.

Based on the presence or absence of cirrhosis and/or HCC the studied subjects were categorized into 3 groups; the demographic, clinical laboratory data, and Child score classification of patients with groups I \& II (patients having cirrhosis with or without HCC) are shown in Tables 1 and 2. As regards group III, apparently, the healthy control group (no cirrhosis or HCC), their mean age was $60.5 \pm 8$ years and $80 \%$ of them were male. Regarding the size of the liver and spleen, there was no statistically significant difference between groups I \& II as regard splenomegaly. However, there
Table 1 Comparison between the study groups (I and II) as regards demographic, clinical, and laboratory data at baseline

\begin{tabular}{|c|c|c|c|}
\hline & $\begin{array}{l}\text { Group I } \\
n=30\end{array}$ & $\begin{array}{l}\text { Group II } \\
n=30\end{array}$ & $P$ value \\
\hline HBV & $6.7 \%$ & $0.0 \%$ & 0.31 \\
\hline $\mathrm{HCV}$ & $80.0 \%$ & $80.0 \%$ & 1.00 \\
\hline Unknown & $13.3 \%$ & $20.0 \%$ & 0.62 \\
\hline DM & $16.7 \%$ & $13.4 \%$ & 0.76 \\
\hline Hypertension & $16.7 \%$ & $23.4 \%$ & 0.67 \\
\hline History of ascites & $70.0 \%$ & $50.0 \%$ & 0.36 \\
\hline $\begin{array}{l}\text { History of lower } \\
\text { limb edema }\end{array}$ & $80.0 \%$ & $50.0 \%$ & 0.16 \\
\hline Abdominal pain & $46.7 \%$ & $10.0 \%$ & 0.06 \\
\hline Abdominal tenderness & $10.0 \%$ & $10.0 \%$ & 1.00 \\
\hline Bleeding tendency & $56.7 \%$ & $53.3 \%$ & 0.71 \\
\hline History of GIT bleeding & $36.7 \%$ & $40.0 \%$ & 0.79 \\
\hline $\begin{array}{l}\text { History of hepatic } \\
\text { encephalopathy }\end{array}$ & $53.3 \%$ & $46.7 \%$ & 0.61 \\
\hline $\begin{array}{l}\text { Clinical presence } \\
\text { of hepatic encephalopathy }\end{array}$ & $73.3 \%$ & $60.0 \%$ & 0.71 \\
\hline $\mathrm{Hb}($ mean $\pm \mathrm{SD})$ & $10.82 \pm 2.43$ & $9.16 \pm 2.85$ & 0.09 \\
\hline WBCs (mean $\pm S D$ ) & $7.70 \pm 3.76$ & $6.25 \pm 4.14$ & 0.23 \\
\hline Platelets (mean \pm SD) & $143.40 \pm 67.63$ & $93.70 \pm 80.59$ & 0.03 \\
\hline Albumin (g/dl) & $2.8 \pm 0.7$ & $2.6 \pm 0.5$ & 0.10 \\
\hline Total bilirubin (mg/dl) & $3.14 \pm 2.9$ & $3.5 \pm 3.7$ & 0.61 \\
\hline ALT (IU/I) & $68.3 \pm 20.2$ & $65.5 \pm 20$ & 0.21 \\
\hline AST (IU/I) & $54.2 \pm 15.8$ & $48.1 \pm 8$ & 0.18 \\
\hline PT (s) & $16.8 \pm 6.7$ & $16.6 \pm 1.8$ & 0.83 \\
\hline Creatinine (mg/dl) & $1.6 \pm 0.9$ & $1.8 \pm 0.9$ & 0.71 \\
\hline P.V.T & $26.7 \%$ & $0.0 \%$ & NA \\
\hline Metastasis & $0.0 \%$ & $0.0 \%$ & NA \\
\hline
\end{tabular}

Bold values indicate significance

There was no statistically significant difference between groups I \& II as regards demographic, clinical, and laboratory data at baseline

was a significant increase in hepatomegaly in group I in comparison to group II $(P$ value $=0.013)$. Staging of HCC cases according to BCLC staging: 5 cases were early stage (A), 5 cases were intermediate stage (B), 3 cases were advanced stage $(\mathrm{C})$, and 17 cases were terminal stage (D) [23]. As regards the HFL detection, US revealed that $10 \%$ of the cases had heterogenous

Table 2 Comparison between the study groups (I and II) as regards child score at baseline

\begin{tabular}{lllll}
\hline & & Group I & Group II & $P$ value \\
\hline Child score & A & $16.7 \%$ & $13.3 \%$ & 0.822 \\
& B & $23.3 \%$ & $30.0 \%$ & \\
& C & $60.0 \%$ & $56.7 \%$ & \\
\hline
\end{tabular}

Bold values indicate significance 
Table 3 Comparison between the study groups (I and II) as regards EGD findings

\begin{tabular}{llllll}
\hline & Group I & Group II & $P$ value & Endothelin-1 level (mean \pm SD) & $P$ value \\
\hline EGD & & $13.3 \%$ & $10.0 \%$ & $<\mathbf{0 . 0 0 1}$ & $4.705 \pm 1.3$ \\
Findings & Grade 2 varices & $20.0 \%$ & $20.0 \%$ & & $6.150 \pm 1.7$ \\
& Grade 3 varices & $23.3 \%$ & $50.0 \%$ & & $5.505 \pm 2.22$ \\
& Grade 4 varices & $13.3 \%$ & $0.0 \%$ & & $7.725 \pm 1.56$ \\
& Mild PHG & $16.7 \%$ & $10.0 \%$ & & $4.307 \pm 2.24$ \\
& Not done & $13.3 \%$ & $10.0 \%$ & & \\
\hline
\end{tabular}

EGD esophago-gastro-duodenoscopy, PHG portal hypertensive gastropathy Bold values indicate significance

lesions, 33.3\% had multiple lesions, and $56.7 \%$ had single HFL. While the CT revealed $50 \%$ of the cases had multiple lesions and $50 \%$ had a single lesion. There was statistically significant increase in EGD findings as regards studied groups showing increase in grading of varices in group I in comparison to group II ( $P$ value is $<0.001$; Table 3). Endothelin-1 has significant positive correlation with AFP in group I $(R=0.6, P$ value < 0.001). However, it has no correlation with AFP in group II. Moreover, there was no statistically significant correlation between endothelin-1 level and portal vein thrombosis in group I (Table 4). ROC analysis of AFP in group I versus group II showed that the cutoff point is $\geq 25.5 \mathrm{ng} / \mathrm{ml}$, AUC (Area Under the Curve) is 0.14 , $30 \%$ sensitivity, and $24 \%$ specificity. While group II versus group III showed that the cutoff point is $\geq 7 \mathrm{ng} / \mathrm{ml}$, AUC is $0.94,91 \%$ sensitivity, and $70 \%$ specificity (Table 5). On the other hand, endothelin-1 in group I versus group II showed that at the cutoff point $>5.2 \mathrm{pg} / \mathrm{ml}$, AUC is $0.98,90 \%$ sensitivity, $100 \%$ specificity, $100 \%$ positive predictive value, and $90.9 \%$ negative predictive value, while endothelin-1 in group II versus group III showed that at the cutoff point $>2.4 \mathrm{pg} / \mathrm{ml}$, AUC is $1,100 \%$ sensitivity, specificity, positive predictive value and negative predictive value (Table 6).

\section{Discussion}

Hepatocellular carcinoma $(\mathrm{HCC})$ is one of the most common malignant tumors. It occurs in more than $90 \%$ of cases in patients with cirrhosis. HCC occurs in most of its cases in patients with liver cirrhosis, which usually develops following chronic liver inflammation caused by hepatitis C (HCV) or B (HBV) virus. Because of high prevalence of $\mathrm{HCV}$ in Egypt and cirrhosis therefore, HCC represents an important public health problem in Egypt. Surveillance of cirrhotic patients is recommended by European and American societies. All patients with cirrhosis are candidates for surveillance regardless of the cause of the underlying liver disease. A number of serum markers have been proposed and several are currently used in clinical practice as a method for HCC diagnosis. The endothelins (ETs) are a family of genes consisting of three 21-amino-acid proteins including peptides (ET-1, ET-2, and ET-3), at first described as vasoconstrictors. Studies have found that ET- 1 and its receptors are over expressed in many cancers. Our study showed that there was a statistically significant increase in ET-1 level in liver cirrhosis group in comparison to the normal control group. We also found that ET-1 has no correlation with alpha-fetoprotein level in liver cirrhosis $(P$ value $=$ $0.503)$. These results were consistent in immunoperoxidase study, Western blot, immunogold electron microscopic study, and in situ hybridization. Immunogold electron microscopy clearly localized endothelin B receptor (ETBR) on hepatic stellate cells (HSCs) and sinusoidal endothelial cells (SECs), and morphometric analysis showed marked increase in ETBR expression on HSCs and SECs in cirrhotic liver [24]. Also, it is consistent with what is believed for more than a decade that there has been major interest in the possible role of ET-1 in the pathogenesis of cirrhosis, its contribution to portal hypertension, and the possibility that

Table 4 Comparison between the study groups as regards AFP and endothelin-1 levels

\begin{tabular}{|c|c|c|c|c|c|c|c|c|}
\hline & \multicolumn{2}{|l|}{ Group I } & \multicolumn{2}{|c|}{ Group ॥ } & \multicolumn{2}{|c|}{ Group III } & \multicolumn{2}{|c|}{ One-way ANOVA } \\
\hline & Mean & SD & Mean & SD & Mean & SD & $\bar{F}$ & $P$ value \\
\hline AFP & 3394.15 & 1989.31 & 17.11 & 9.10 & 1.24 & 0.35 & 2.846 & 0.063 \\
\hline \multirow[t]{2}{*}{ Endothelin-1 } & 8.18 & 0.76 & 4.68 & 1.15 & 1.56 & 0.61 & 432.377 & $<0.001$ \\
\hline & \multicolumn{2}{|c|}{ Group I VS Group II } & \multicolumn{3}{|c|}{ Group I VS Group III } & \multicolumn{3}{|c|}{ Group II VS Group III } \\
\hline Endothelin-1 & \multicolumn{2}{|l|}{$<0.001$} & \multicolumn{3}{|c|}{$<0.001$} & \multicolumn{3}{|c|}{$<0.001$} \\
\hline
\end{tabular}


Table 5 Cutoff point, sensitivity, and specificity of AFP between different groups

\begin{tabular}{lllll}
\hline Variable & Cutoff point & AUC, 95\% Cl & Sensitivity & Specificity \\
\hline Group I versus group II & $\geq 25.5 \mathrm{ng} / \mathrm{ml}$ & $0.14(0.1-0.28)$ & $30 \%$ & $24 \%$ \\
Group II versus group III & $\geq 7 \mathrm{ng} / \mathrm{ml}$ & $0.94(0.87-0.99)$ & $91 \%$ & $70 \%$
\end{tabular}

$A U C$ area under the curve, $\mathrm{Cl}$ confidence interval

endothelin antagonists might be used in the treatment of portal hypertension [25, 26]. Matrix metalloproteinases (MMPs) have significant role in tumor invasion and metastasis processes [27]. Activation of endothelin (A) receptor (ETAR) was found to upregulate the expression and secretion of MMP-3 in HCC cells [28]. Raised levels of ET-1 in specimens of various cancers are also well established. ETAR has been implicated in growth, migration, and metastasis of many tumors [29]. Patients with primary or metastatic colorectal cancers are found to have elevated plasma ET-1 levels [18, 30]. ET receptors are over expressed in specimens of prostate [31, 32], breast [33], and lung cancer [32]. Kitagawa et al. demonstrated significant cellular proliferation in human meningioma cells in response to ET-1 [33]. Ovarian cancer cell lines produce ET1 and have ETA receptors [34] and ET-1 was found to enhance the migration of human chondrosarcoma [35]. ET-1 has previously been demonstrated to serve an important role in other human cancers such as bladder cancer [34]. Increased levels of ET-1 have been reported previously in HCC [36, 37]. Serum ET-1 is increased in HCC patients and it is related to the tumor size [38]. In a recent study, it was found that ETAR, but not ETBR was over expressed in HCC cells [28].

ET-1 secretion in HCC is stimulated by many cytokines and growth factors [39]. Elevated levels of ET-1 have been observed in HCC tissues compared with normal liver tissues [40]. It has previously been established that ET-1 upregulation increases HCC cell proliferation, invasion and migration, and inhibits apoptosis [41]. Furthermore, microRNA-1 is able to inhibit HCC cell proliferation partially by targeting ET-1 [42]. The results of a study, by Lu et al., indicate that liver expression of ET-1 induces hepatocarcinogenesis [43]. Our study showed that there was a statistically significant increase in ET-1 level in HCC in comparison to liver cirrhosis and normal control $(P$ value $<0.001)$. In another study, increased levels of endothelin 1 (ET-1) and nitrites and nitrates (NOx, the end products of NO metabolism) have been documented in hepatocellular carcinoma. Eighteen patients with virus-related HCC (six Okuda stage I, six Okuda stage II, and six Okuda stage III) were included in the study and were compared with 22 patients with viral cirrhosis (14 decompensated, eight compensated) and seven normal controls. ET-1 was measured with an ELISA assay. Compared with decompensated cirrhosis patients $(9.57 \pm 0.32 \mathrm{pg} / \mathrm{ml})$, compensated cirrhosis patients $(9.46 \pm 0.50 \mathrm{pg} / \mathrm{ml})$ and controls $(8.84 \pm 0.61 \mathrm{pg} / \mathrm{ml})$, serum levels of ET-1 in patients with HCC were significantly higher $(13.25 \pm 0.82 \mathrm{pg} / \mathrm{ml}$, $P<0.001, P<0.004$, and $P<0.001$, respectively). When HCC patients were grouped according to the Okuda staging system all groups had ET-1 levels that were higher than decompensated cirrhosis, compensated cirrhosis, and the controls (stage I $11.88 \pm 0.90 \mathrm{pg} / \mathrm{ml}$, stage II $11.89 \pm$ $0.44 \mathrm{pg} / \mathrm{ml}$, stage III $15.98 \pm 1.92)$. Only HCC stage III had significantly higher ET-1 levels compared to all other groups $(P<0.03$ in all cases). Patients with decompensated cirrhosis and compensated cirrhosis had slightly higher mean levels of serum ET-1 from the controls but no statistically significant difference was established [14]. In our study, we found that at cutoff value $5.2 \mathrm{pg} / \mathrm{ml}$ for ET-1 in HCC group, sensitivity, specificity, and positive and negative predictive values were calculated $(90 \%, 100 \%, 100 \%$, $90.9 \%$, respectively) suggesting high sensitivity \& specificity of ET-1 for diagnosis of HCC. ET-1 expression as well as ETAR expression was associated with vascular invasion and tumor stage in HCC [28]. As regard vascular spread of HCC (proven by presence of portal vein invasion), we found - in our study - that there was no statistically significant association between endothelin-1 and portal vein thrombosis in HCC $(P$ value $=0.547)$. This means that endothelin-1 is less accurate in determination of vascular invasion of the tumor.

\section{Conclusion}

Serum level of endothelin-1 is of high sensitivity \& specificity in the diagnosis of hepatocellular carcinoma. However, its value in prediction of its vascular spread is limited.

Table 6 Cutoff point, sensitivity, and specificity of endothelin-1 between different groups

\begin{tabular}{|c|c|c|c|c|c|c|}
\hline & Cutoff point & $A \cup C$ & Sensitivity & Specificity & -PV & $+P V$ \\
\hline Group I versus group II & $>5.2 \mathrm{~g} / \mathrm{ml}$ & 0.982 & 90 & 100 & 90.9 & 100 \\
\hline Group II versus group III & $>2.4 \mathrm{pg} / \mathrm{ml}$ & 1.000 & 100 & 100 & 100 & 100 \\
\hline
\end{tabular}

$\overline{A U C}$ area under the curve, $-P V$ negative predictive value, $+P V$ positive predictive value 


\section{Abbreviations}

AFP: Alpha-fetoprotein; ANOVA: One-way analysis of variance; AUC: Area under the curve; CBC: Complete blood count; $C \mathrm{CT}$ : Computerized tomography; EDTA: Ethylene Diamine Tetra Acetic Acid; ET: Endothelin; ETAR: Endothelin A receptor; ETBR: Endothelin B receptor; HBV: Hepatitis B virus; HCC: Hepatocellular carcinoma; HCV: Hepatitis C virus; HRP: Horse radish peroxidase; HSC: Hepatic stellate cells; IQR: Inter quartile range; IRB: Institutional Review Board; MMP: Matrix metalloproteinases; NO: Nitric oxide; NPV: Negative predictive value; OD: Optical density; PPV: Positive predictive value; ROC: Receiver operating characteristic; SD: Standard deviation; SECs: Sinusoidal endothelial cells; SPSS: Statistical Package for Social Science; TMB: Tetra-methyl-benzidine; US: Ultrasound scans

\section{Acknowledgements}

We wish to express my great magnitude to all those who assisted us to complete this work in the Tropical Medicine Department, Faculty of Medicine, Aswan University.

\section{Authors' contributions}

All authors read and approved the final manuscript. ME is a Lecturer of Tropical Medicine \& Gastroenterology Department at the Faculty of Medicine, Aswan University (The first author) and designed the work. EFA is a Professor of Tropical Medicine \& Gastroenterology Department at the Faculty of Medicine, Assuit University, and revised the work. EFM is a Lecturer of Clinical Pathology Department at the Faculty of Medicine, Aswan University, and interpreted the data of the work. MT is an Assistant lecturer of Tropical Medicine \& Gastroenterology Department at the Faculty of Medicine, Aswan University, and is the corresponding author of the work.

\section{Funding}

None

\section{Availability of data and materials}

Data and material were available for the study.

\section{Ethics approval and consent to participate}

The study was performed according to the ethical guidelines of the 1975 Declaration of Helsinki after approval from Institutional Review Board (IRB) for human subject research at Aswan University Hospital (Serial: aswu/84/9/16). Informed consents were obtained from all enrolled participants before enrollment to the study.

\section{Consent for publication}

Non applicable

\section{Competing interests}

The authors have no conflicts of interest to declare.

\section{Author details}

'Tropical Medicine and Gastroenterology Department, Faculty of Medicine, Aswan University, Aswan, Egypt. ${ }^{2}$ Clinical Pathology Department, Faculty of Medicine, Aswan University, Aswan, Egypt. ${ }^{3}$ Tropical Medicine and Gastroenterology Department, Faculty of Medicine, Assuit University, Assuit, Egypt.

Received: 28 November 2019 Accepted: 19 March 2020

Published online: 03 June 2020

\section{References}

1. Bertuccio P, Turati F, Carioli G, Rodriguez T et al (2017) Global trends and predictions in hepatocellular carcinoma mortality. J Hepatol 67(2):302-309

2. Goldman R, Ressom HW, Abd el-hamid M et al (2007) Candidate markers for the detection of hepatocellular carcinoma in low molecular weight fraction of serum. Carcinogenesis 28(10):2149-2153

3. Oishi K, Itamoto T, Amano H, Fukuda S et al (2007) Clinico-pathologic features of poorly differentiated hepatocellular carcinoma. J Surg Oncol 95: 311-316

4. Maeda T, Shimada M, Harimoto N, Tsujita E et al (2008) Prognosis of early hepatocellular carcinoma after hepatic resection. Hepatogastroenterology 55:1428-1432
5. Bruix J, Sherman M (2005) Diagnosis of small HCC. Gastroenterology 129(4):1364

6. Kawada K, Hasegawa S, Murakami T et al (2011) Molecular mechanisms of liver metastasis. Int J Clin Oncol 16(5):464-472

7. Dutta R, Mahato RI (2017) Recent advances in hepatocellular carcinoma therapy. Pharmacol Ther 173:106-117

8. Ayuso C, Rimola J, Vilana R, Burrel M et al (2018) Diagnosis and staging of hepatocellular carcinoma (HCC): current guidelines. Eur J Radiol 101:72-81

9. Soresi M, Terranova A, Licata A, Serruto A, Montalto G, Brancatelli G, Giannitrapani L (2017) Surveillance program for diagnosis of HCC in liver cirrhosis: role of ultrasound echo patterns. Biomed Res Int 2017:4932759

10. Forner A, Reig M, Bruix J (2009) Alpha-fetoprotein for hepatocellular carcinoma diagnosis: the demise of a brilliant star. Gastroenterology 137:26-29

11. Housset C, Rockey DC, Bissell M (1993) Endothelin receptors in rat liver: lipocytes as a contractile target for endothelin-1. Proc Natl Acad Sci U S A 90:9266-9270

12. Wang R, Dashwood RH (2011) Endothelins and their receptors in cancer: identification of therapeutic targets. Pharmacol Res 63(6):519-524

13. Unic A, Derek L, Hodak N et al (2011) Endothelins-clinical perspectives. Biochem Med 21(3):231-242

14. Notas G, Xidakis C, Valatas V, Kouroumalis A, Kouroumalis E (2001) Levels of circulating endothelin-1 and nitrates/nitrites in patients with virus-related hepatocellular carcinoma. J Viral Hepat 8(1):63-69

15. Pinto A, Merino M, Zamora P, Redondo A, Castelo B, Espinosa E (2012) Targeting the endothelin axis in prostate carcinoma. Tumour Biol 33(2):421-426

16. Rockey DC (2015) Endothelial dysfunction in advanced liver disease. Am J Med Sci 349(1):6-16

17. Borzacchiello G, Mogavero S, Tortorella G, Catone G, Russo M (2010) Expression of endothelin-1 and endothelin receptor a in canine ovarian tumours. Reprod Domest Anim 45(6):465-468

18. Liakou P, Tepetes K, Germenis A et al (2012) Expression patterns of endothelin-1 and its receptors in colorectal cancer. J Surg Oncol 105(7): 643-649

19. Irani S, Salajegheh A, Gopalan V, Smith RA, Lam AK (2014) Expression profile of endothelin-1 and its receptor endothelin receptor $\mathrm{A}$ in papillary thyroid carcinoma and their correlations with clinic-pathologic characteristics. Ann Diagn Pathol 18(2):43-48

20. Carducci MA, Jimeno A (2006) Targeting bone metastasis in prostate cancer with endothelin receptor antagonists. Clin Cancer Res 12(20 Pt 2):6296-6300

21. Lu JW, Liao CY, Yang WY et al (2014) Overexpression of endothelin 1 triggers hepatocarcinogenesis in zebrafish and promotes cell proliferation and migration through the AKT pathway. PLoS One 9(1):e85318

22. Perkins NJ, Schisterman EF (2005) The Youden index and the optimal cutpoint corrected for measurement error. Biom J 47(4):428-441

23. Forner A, Reig M, Burix J (2018) Hepatocelluler carcinoma. Lancet 391(10127):1301-1314. https://doi.org/10.1016/50140-6736 (18) 30010-2

24. Yokomori H, Oda M, Yasogawa Y, Nishi Y, Ogi M, Takahashi M, Ishii H (2001) Enhanced expression of endothelin B receptor at protein and gene levels in human cirrhotic liver. Am J Pathol 159(4):1353-1362

25. Helmy A, Jalan R, Newby DE et al (2001) Altered peripheral vascular responses to exogenous and endogenous endothelin-1 in patients with well compensated cirrhosis. Hepatology 33:826-831

26. Moore K (2004) Endothelin and vascular function in liver disease. Gut 53: $159-161$

27. Bauvois B (2012) New facets of matrix metalloproteinases MMP-2 and MMP9 as cell surface transducers: outside-in signaling and relationship to tumor progression. Biochim Biophys Acta 1825(1):29-36

28. Cong N, Li Z, Shao W, Li J, Yu S (2016) Activation of ETA receptor by endothelin-1 induces hepatocellular carcinoma cell migration and invasion via ERK1/2 and AKT signaling pathways. J Membr Biol 249(1-2):119-128

29. Guise TA, Mohammad KS (2004) Endothelins in bone cancer metastases. Cancer Treat Res 118:197-212

30. Asham E, Loizidou M, Lakhani S, Miller K, Burnstock G et al (1997) Expression of endothelin-1 in 98 patients with colorectal cancer. Eur J Surg Oncol 23:589

31. Rosenblatt R, Valdman A, Cheng L et al (2009) Endothelin-1 expression in prostate cancer and high grade prostatic intraepithelial neoplasia. Anal Quant Cytol Histol 31(3):137-142

32. Rotondo S, Menard J, Durlach A, Birembaut P, Staerman F (2012) Endothelin-1 and receptor A: predictive value for biochemical relapse on patients with advanced and metastatic prostate cancer. Prog Urol 22:38-44 
33. Patel KV, Schrey MP (1995) Human breast cancer cells contain a phosphoramidon-sensitive metalloproteinase which can process exogenous big endothelin-1 to endothelin-1: a proposed mitogen for human breast fibroblasts. Br J Cancer 71:442-447

34. Bagnato A, Tecce R, Dicastro V, Catt KJ (1997) Activation of mitogenic signalling by endothelin-1 in ovarian carcinoma cells. Cancer Res 57:1306-1311

35. Wu MH, Chen LM, Hsu HH et al (2013) Endothelin-1 enhances cell migration through COX-2 up-regulation in human chondrosarcoma. Biochim Biophys Acta 1830(6):3355-3364

36. Uchida Y, Watanabe M (1993) Plasma endothelin-1 concentrations are elevated in acute hepatitis and liver cirrhosis but not in chronic hepatitis. Gastroenterol Jpn 28:666-672

37. Matsumoto H, Uemasu J, Kitano M, Kawasaki H (1994) Clinical significance of plasma endothelin-1 in patients with cirrhotic liver disease. Dig Dis Sci 39:2665-2670

38. Nakamuta M, Ohashi M, Tabata S et al (1993) High plasma concentrations of endothelin-like immunoreactivities in patients with hepatocellular carcinoma. Am J Gastroenterol 88:248-252

39. Gressner AM, Weiskirchen R (2006) Modern pathogenetic concepts of liver fibrosis suggest stellate cells and TGF beta as major players and therapeutic targets. J Cell Mol Med 10:76-99

40. Pfab T, Stoltenburg Didinger G, Trautner C, Godes M, Bauer C, Hocher B (2004) The endothelin system in Morris hepatoma 7777: an endothelin receptor antagonist inhibits growth in vitro and in vivo. Br J Pharmacol 141: $215-222$

41. Lu JW, Hsia Y, Yang WY, Lin Yl, Li CC, Tsai TF, Chang KW et al (2012) Identification of the common regulators for hepatocellular carcinoma induced by hepatitis B virus $X$ antigen in a mouse model. Carcinogenesis 33:209-219

42. Li D, Yang P, Li H, Cheng P et al (2012) MicroRNA 1 inhibits proliferation of hepatocarcinoma cells by targeting endothelin 1. Life Sci 91:440-447

43. Shi L, Zhou SS, Chen WB, Xu L (2017) Functions of endothelin-1 in apoptosis and migration in hepatocellular carcinoma. Exp Ther Med 13(6): 3116-3122

\section{Publisher's Note}

Springer Nature remains neutral with regard to jurisdictional claims in published maps and institutional affiliations.

\section{Submit your manuscript to a SpringerOpen ${ }^{\circ}$ journal and benefit from:}

- Convenient online submission

- Rigorous peer review

- Open access: articles freely available online

- High visibility within the field

- Retaining the copyright to your article

Submit your next manuscript at $\boldsymbol{\nabla}$ springeropen.com 